\title{
Conceptual approaches for incorporating climatic change into the development of forest management options for sequestering carbon
}

\author{
George A. King \\ ManTech Environmental Technology, Inc., U.S. EPA Environmental Research Laboratory, 200 SW 35th St., Corvallis, \\ Oregon 97333, USA
}

\begin{abstract}
The potential for significant environmental change over the next $100 \mathrm{yr}$ has resulted in efforts to develop mitigation options for reducing the rate of increase of carbon dioxide concentrations in the atmosphere. One of the more promising options is management of forest and agroforestry systems. However, most assessments of the potential of forest management options to sequester carbon have not factored future environmental change (climate and $\mathrm{CO}_{2}$ concentration) into their analyses. Climate and ecological models that could be used to incorporate environmental change into forest mitigation planning efforts are reviewed in this paper in terms of their relative strengths and limitations for this particular application. Recommendations are then made as to how to use the available models to estimate the global and regional potential for sequestering carbon in the terrestrial biosphere, incorporating future environmental change into the analyses. Recommendations are also made as to how to target the most promising regions for reforestation efforts given the likelihood of future environmental change.
\end{abstract}

\section{INTRODUCTION}

Management of forest and agroforestry systems to increase the storage of carbon in the terrestrial biosphere appears to be a promising option in slowing the increase in atmospheric concentrations of $\mathrm{CO}_{2}$ (Dixon et al. 1991, Schroeder \& Ladd 1991, Sampson 1992, Sampson \& Hair 1992, Trexler et al. 1992, Winjum et al. 1992). However, many of the studies that have explored reforestation, afforestation, and agroforestry as mechanisms to sequester carbon have not quantitatively factored in the potential for climate change and enhanced concentrations of $\mathrm{CO}_{2}$ to affect future forest growth (e.g. Birdsey 1992, Sampson 1992, Trexler et al. 1992). This is a difficult task because of limitations both in our understanding of how forests will respond to higher levels of $\mathrm{CO}_{2}$ and in our models to predict future climate and forest growth. Still, there are climate and ecological models available at this time that can be incorporated into analyses of the potential for managing forest systems to sequester carbon. Doing so will render the resulting plans more realistic and policy relevant.
In this paper, our current understanding of climate change and its potential environmental impacts is summarized first in order to provide a strong justification for why changing environmental conditions must be factored into mitigation planning efforts. Next, climate and ecological models that can be used to simulate climate change and its impact are described, and then some recommendations are proposed on how to incorporate the available models and hence climate change into mitigation planning efforts.

\section{POTENTIAL MAGNITUDE OF CLIMATE CHANGE AND ELEVATED $\mathrm{CO}_{2}$ EFFECTS ON FOREST DISTRIBUTION AND PRODUCTIVITY}

\section{Future climate change}

Over the past few years the Intergovernmental Panel on Climate Change (IPCC) has been reviewing climate model simulations to evaluate the potential effect of a radiatively equivalent doubling of carbon 
dioxide concentrations on global climate (Houghton et al. 1990, 1992). They have concluded that a radiatively effective doubling of the atmospheric $\mathrm{CO}_{2}$ concentration would likely change the average global temperature between 1.5 and $4.5^{\circ} \mathrm{C}$ after equilibrium conditions were reached. The current best guess value is $2.5^{\circ} \mathrm{C}$. Temperatures would increase more at high latitudes than low latitudes (Fig. 1). Over the forested regions of the eastern United States, grid point estimates of increases in July temperature from 3 general circulation model (GCM) simulations (GISS, Hansen et al. 1988; OSU, Schlesinger \& Zhao 1989; and GFDL, Manabe \& Wetherald 1987) range from $2.1^{\circ} \mathrm{C}$ (GISS model) to $9.4^{\circ} \mathrm{C}$ (GFDL model). Global precipitation (and evaporation) would increase 3 to $15 \%$.
The rate of climate change is of great importance from mitigation planning and climate impact perspectives. If the above changes in climate were expected to occur over a thousand-year time frame, they would have little environmental impact over the length of most forest rotation periods. However, large climate changes are expected to occur over the next 50 to $100 \mathrm{yr}$, equivalent to 1 or 2 forest rotations. Specifically, the IPCC has developed a set of future greenhouse gas emissions scenarios for the period from 1990 to 2100 using different assumptions on future economic growth, agricultural development, and population growth (Houghton et al. 1990, 1992). These scenarios are then used to determine changes in radiative forcing over that same time period. This information is in turn input into a simple box-diffusion-upwelling cli-
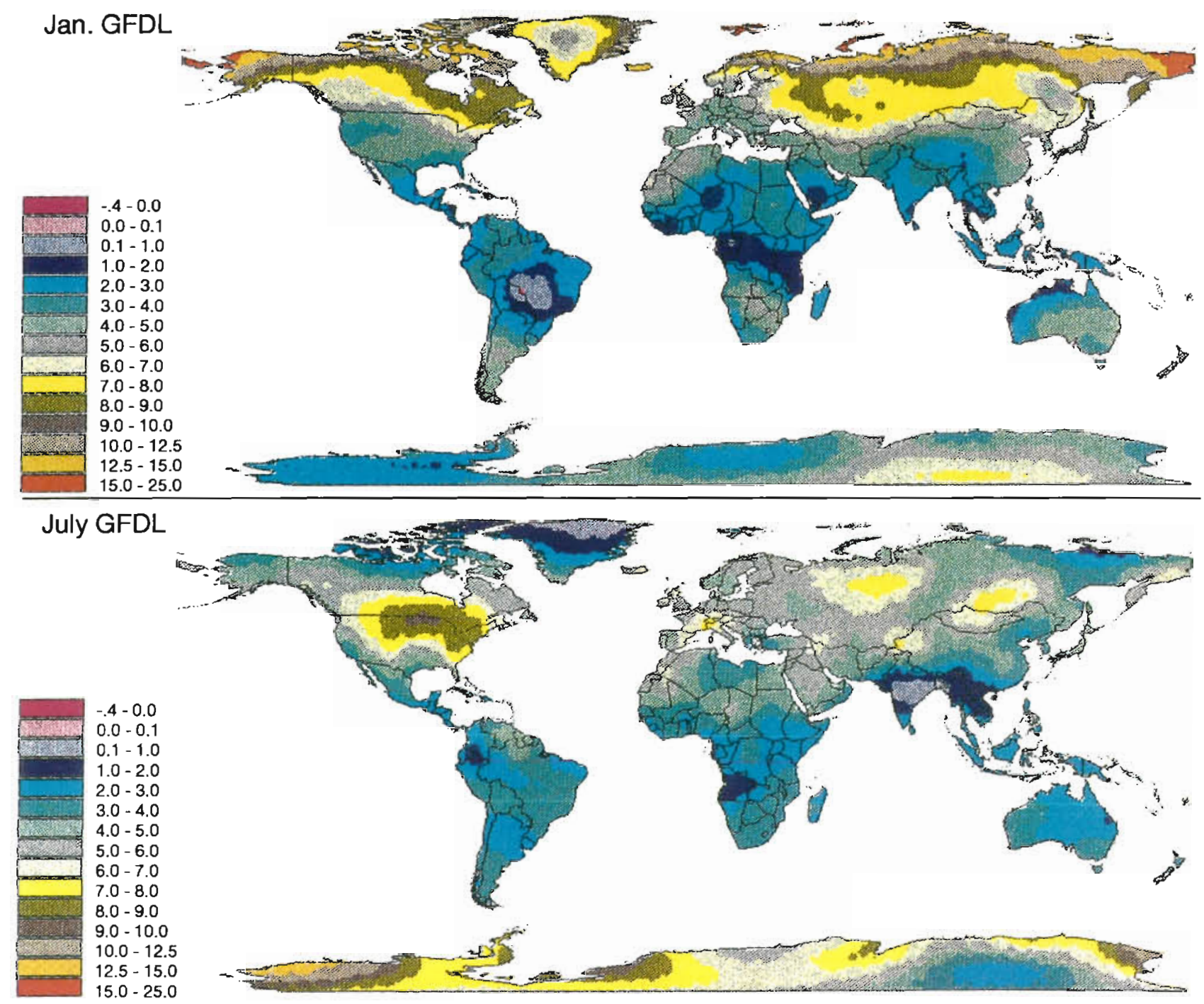

Fig. 1. Differences between $2 \times \mathrm{CO}_{2}$ and $1 \times \mathrm{CO}_{2}$ simulations of mean surface air temperature $\left({ }^{\circ} \mathrm{C}\right)$ for January and July as produced by the GFDL model (Manabe \& Wetherald 1987). The GFDL temperature data, which is simulated at $4^{\circ} \times 5^{\circ}$ resolution for the globe, was interpolated to a $0.5^{\circ} \times 0.5^{\circ}$ grid for this map 


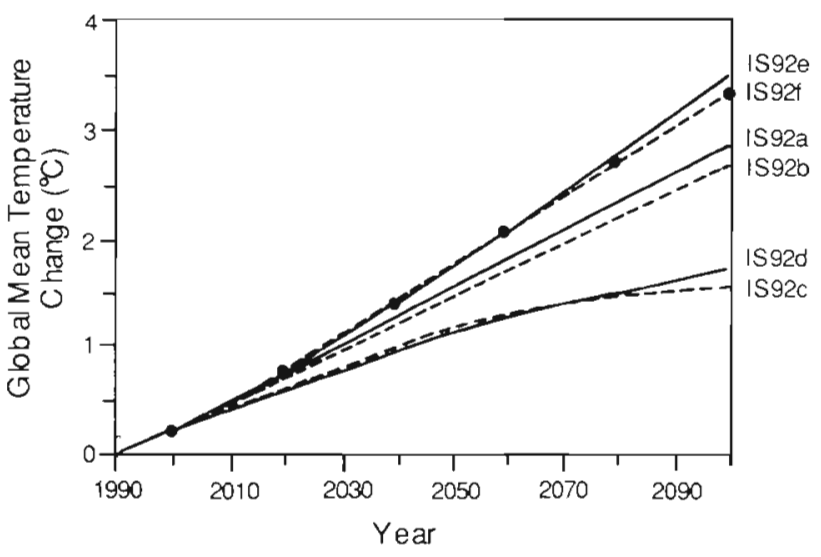

Fig. 2. Best estimate of future climate change assuming a $2.5^{\circ} \mathrm{C}$ doubled $-\mathrm{CO}_{2}$ climate sensitivity for IPCC 1992 emission scenarios (IS92a to $f_{\text {; }}$ lines) and the 1990 IPCC 'business as usual' scenario (solid circles). From Houghton et al. (1992)

mate model along with the 'low', 'best', and 'high' estimates of equilibrium doubled- $\mathrm{CO}_{2}$ climate sensitivity (determined from the analysis of $20 \mathrm{GCM}$ simulations) to estimate the time-dependent changes in global mean temperature (Fig. 2). Global mean temperatures are expected to rise $0.3^{\circ} \mathrm{C}$ per decade (based on the 'best estimate' equilibrium response), with a likely range of 0.2 to $0.5^{\circ} \mathrm{C}$. Wigley \& Raper (1992) expanded the IPCC analyses and estimated the (1) effects of $\mathrm{CO}_{2}$ fertilization, (2) feedback effects of stratospheric ozone depletion, and (3) radiative impact of sulphate aerosols on climate using the same simple box-diffusionupwelling climate model. The addition of these other climatic-forcing functions reduced the magnitude and rate of climate change. Their best estimate is $0.2^{\circ} \mathrm{C}$ per decade. Nevertheless, climate change at these rates is unprecedented over the last 10000 yr (Webb 1989).

The rate of climate change has also been estimated using more complex coupled atmosphere-ocean general circulation models. Ocean dynamics and their effects on atmospheric processes are simulated more realistically in these coupled models as opposed to the atmospheric GCMs. These coupled models also simulate warming at a rate of 0.2 to $0.3^{\circ} \mathrm{C}$ per decade (Fig. 3; Houghton et al. 1992).

\section{Direct effects of carbon dioxide}

Increases in the atmospheric concentrations of $\mathrm{CO}_{2}$ alone could change forest productivity through changes in photosynthetic rates and water-use efficiency (WUE). Numerous short-term experimental studies have demonstrated the positive effect of elevated $\mathrm{CO}_{2}$ concentrations on plant growth (see Mooney et al. 1991 and Drake 1992 for recent sum- maries). The growth of broad-leaved and needleleaved tree species increased by 20 to $120 \%$ under doubled $\mathrm{CO}_{2}$ concentrations, with a median about $40 \%$ (Eamus \& Jarvis 1989). The observed increases in plant growth are a direct result of increases in photosynthetic rates caused by higher $\mathrm{CO}_{2}$ concentrations in plant stomata. Stomatal aperture has also been shown to decrease in numerous experiments (Drake 1992). Elevated $\mathrm{CO}_{2}$ concentrations may also increase plant growth by reducing dark respiration (Bunce 1990, Amthor et al. 1992), although the mechanism through which this occurs is uncertain. One important result of these physiological effects is that plant WUE (defined as the number of carbon molecules fixed per molecule of water transpired) increases. This increase in WUE could offset to some degree drought stress imposed by higher temperatures. The extent to which the direct effects of $\mathrm{CO}_{2}$ will ameliorate drought stress depends on the relative balance between the rate and magnitude of increases in drought stress and the rate and magnitude of increase in plant WUE (Neilson \& King 1992). Both of these rates are highly uncertain at this time.

Several significant issues remain unresolved concerning the direct effects of $\mathrm{CO}_{2}$ on plant growth. First, a few studies have shown that some plant species acclimate to the higher $\mathrm{CO}_{2}$ concentrations, with photosynthetic rates at the higher $\mathrm{CO}_{2}$ concentrations gradually decreasing over time (e.g. Tolley \& Strain 1985, Drake 1992). Second, most experiments have been conducted for only one growing season. Studies spanning several years are needed to evaluate the prolonged effects of $\mathrm{CO}_{2}$ on plant growth. Third, relatively few studies have been conducted on tree species, es-

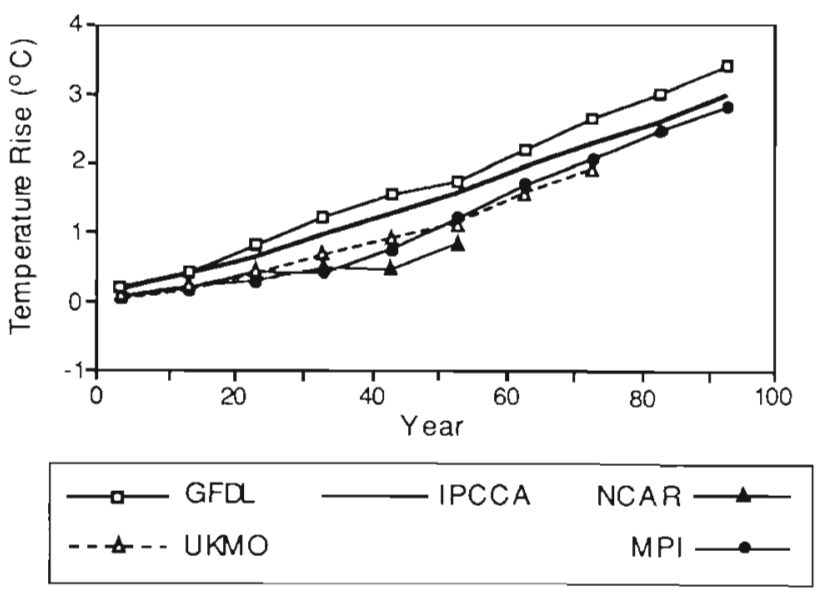

Fig. 3. Transient temperature scenarios from 4 coupled atmosphere-ocean GCM simulations. GFDL = Geophysical Fluid Dynamics Laboratory; UKMO = United Kingdom Meteorological Office; NCAR = National Center for Atmospheric Research; MPI = Max-Planck Institute for Meteorology in Hamburg, Germany; IPCC A = the IPCC 1990 "business as usual' best estimate. From Houghton et al. (1992) 
pecially in combination with changes in temperature and moisture as is likely to occur with climate change. Thus, longer-term studies of common tree species in forest environments are needed to more fully understand the physiological response of the plants to higher $\mathrm{CO}_{2}$ concentrations. This information is needed to modify and calibrate vegetation models, so that the effects of higher $\mathrm{CO}_{2}$ levels on forested ecosystems can be more accurately simulated.

\section{Potential impacts on vegetation}

A wide range of models have been used to simulate the potential impact of climate change on vegetation and forest distribution. All the modeling studies have demonstrated that climate change alone could have a large impact on vegetation distribution. Simulation results from a relatively simple model, the Holdridge Life Zone Classification System (Holdridge 1947, 1967), indicate that 16 to $56 \%$ of the earth's vegetated surface could change from one vegetation type to another, depending on the magnitude of the projected climate change (Smith et al. 1992a, b). In the northern hemisphere, forest zones are simulated to move northward. More process-based broad-scale models that have been developed for Canada [Canadian Climate-

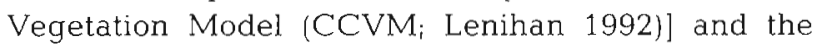
United States [Mapped Atmosphere Plant Soil System (MAPSS); Neilson et al. 1992, R. P. Neilson pers. comm.] show that forest change could be greater than that simulated by the Holdridge model (Figs. 4 \& 5, Table 1; Neilson et al. in press). Depending on the climate change scenario, forest area in the U.S. as simulated by MAPSS could increase by $9 \%$ or decrease by as much as $92 \%$ (Table 1). Savannas generally increase in area in these MAPSS scenarios, with changes in the total area of forest and savanna ranging from an increase of $5 \%$ to a decrease of $61 \%$. Regional application of forest gap models, which are speciesspecific, also demonstrates the potential for widespread forest redistribution (e.g. Solomon 1986, Botkin et al. 1989, Urban \& Shugart 1989, Solomon \& Bartlein 1992). Much of the forest redistribution may occur through a process of drought-induced forest dieback (Solomon 1986, Neilson 1990, King \& Neilson 1992, Solomon \& Bartlein 1992). Furthermore, the rate of climate change could be much faster than the ability of plant species to migrate over relatively flat terrain. For example, in the Northern Hemisphere, climate conditions favoring the growth of temperate deciduous trees could move north faster than the trees could migrate, reducing the actual area occupied by the species (Davis \& Zabinski 1992).

Besides the magnitude and timing of future climate change, the other major uncertainty in the above results is the extent to which the direct effects of carbon dioxide will mitigate drought stress. Unfortunately, few models have been developed to investigate the interactive effects of climate change and carbon

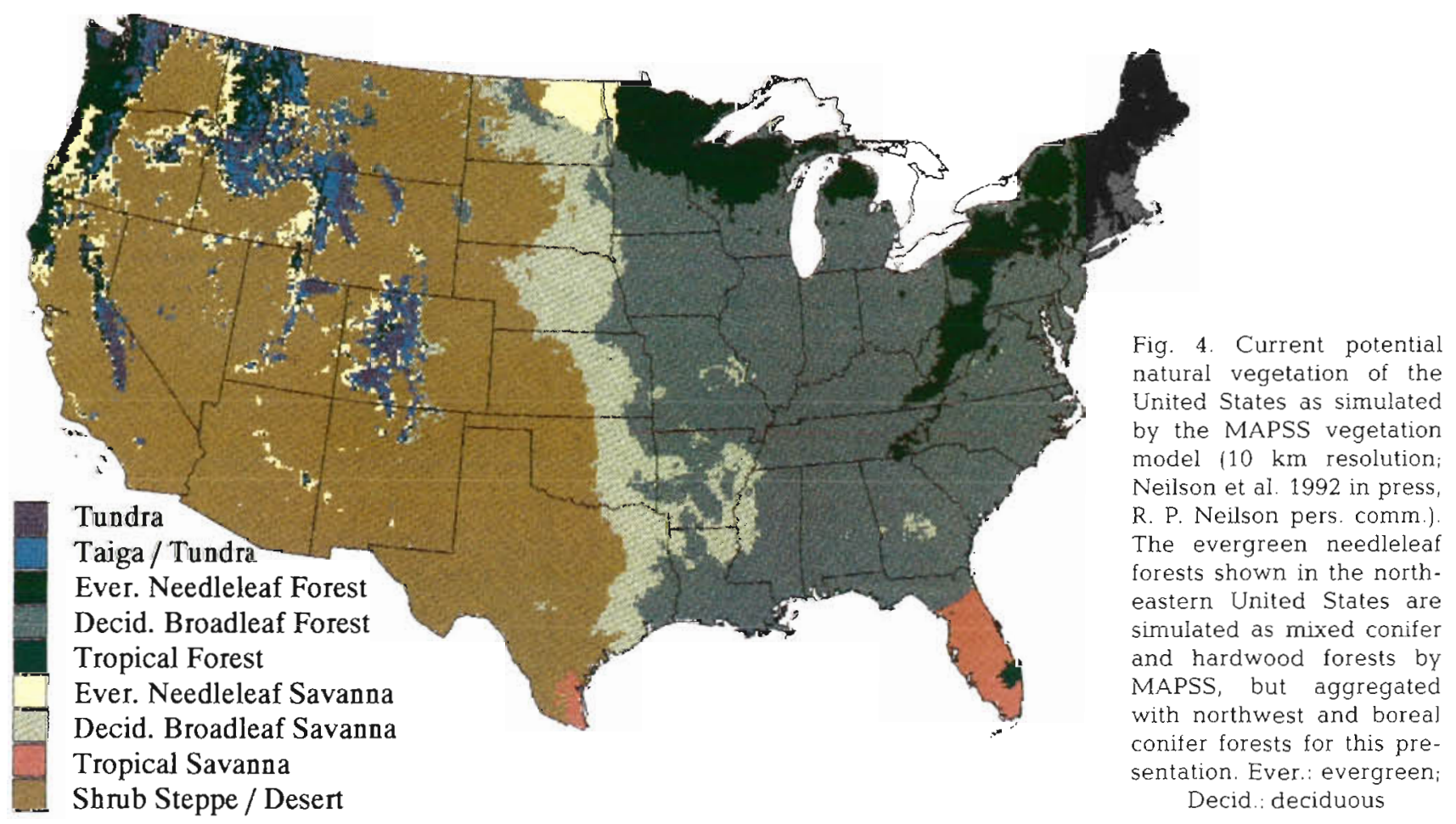



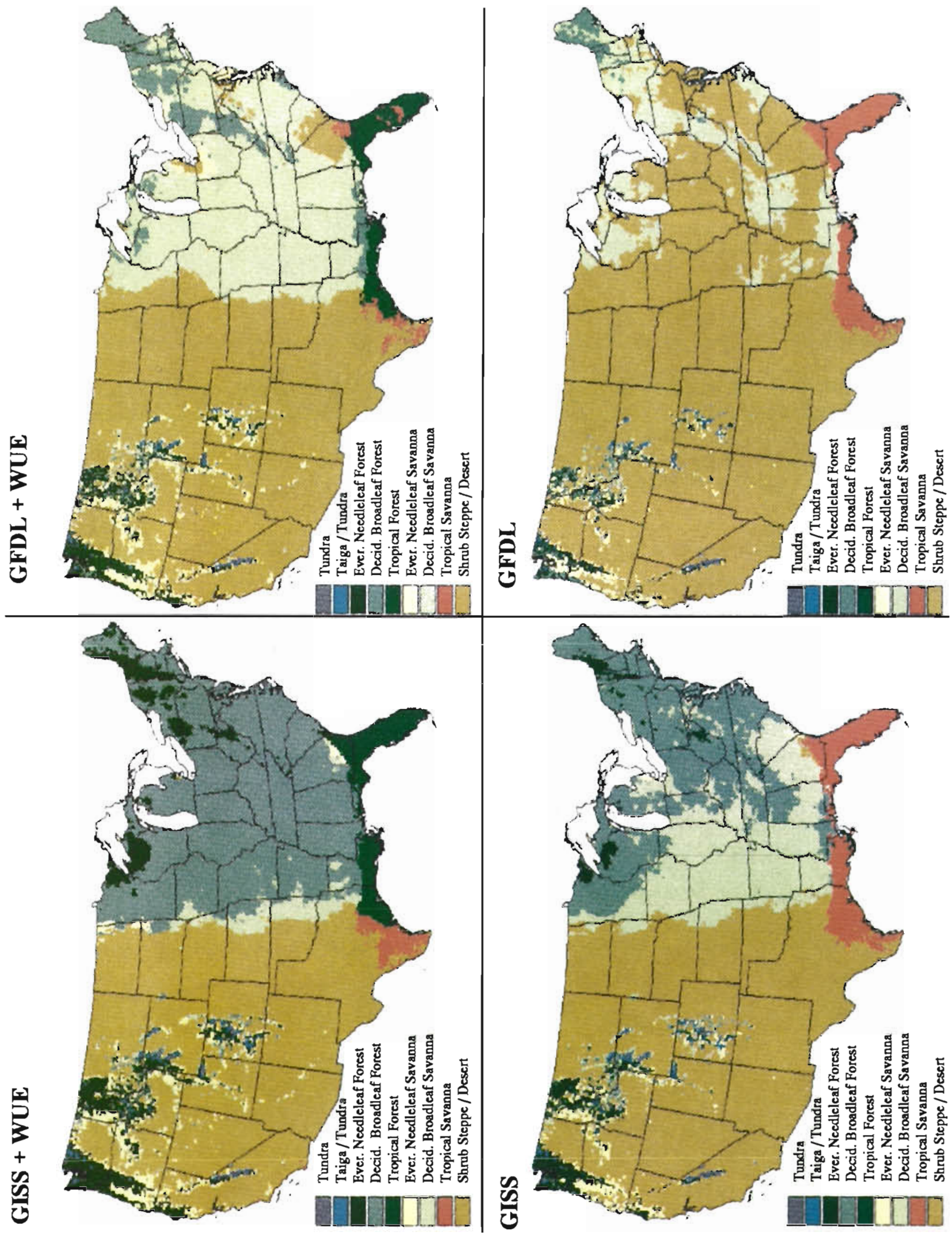

㗤

몬

बे

ये

$\frac{0}{0}$.

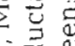

동ํㅇ

$\bar{\tau} \partial$

尊

$\infty \frac{D}{2}$

品 $\cong$

¿

(2)

号要

$\therefore \infty$

थल

U)

导

छี

要步

宁这

용

U.

둥

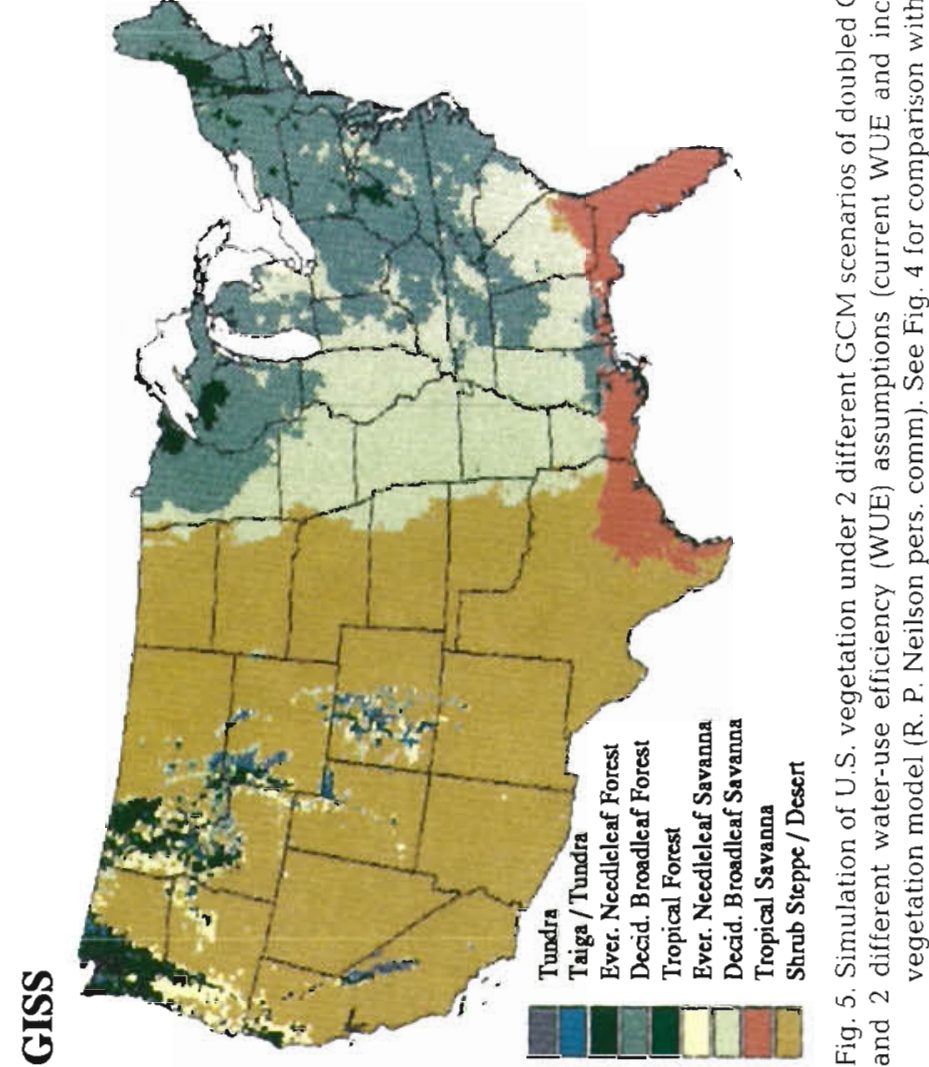


Table 1 Percent future area relative to current area in the conterminous United States of forest and savanna vegetation types as simulated by MAPSS using several different climate and water-use efficiency scenarios (Neilson et al. 1992, in press, R. P. Neilson pers. comm.). See Fig. 5 for maps of these vegetation change scenarios

\begin{tabular}{|c|c|c|c|c|c|c|}
\hline \multirow{2}{*}{$\begin{array}{l}\text { Climate scenario: } \\
\text { MAPSS parameterization } / \\
\text { vegetation type: }\end{array}$} & \multicolumn{3}{|c|}{ GISS $^{d}$} & \multicolumn{3}{|c|}{ GFDL'b } \\
\hline & Forest & Savanna & $\begin{array}{l}\text { Forest + } \\
\text { savanna }\end{array}$ & Forest & Savanna & $\begin{array}{l}\text { Forest + } \\
\text { savanna }\end{array}$ \\
\hline Increased WUE & $109 \%$ & $89 \%$ & $105 \%$ & $30 \%$ & $342 \%$ & $89 \%$ \\
\hline Current WUE & $54 \%$ & $271 \%$ & $95 \%$ & $8 \%$ & $169 \%$ & $39 \%$ \\
\hline
\end{tabular}

dioxide on plant growth. Solomon \& West (1986) modified the growth equation in the forest gap model FORENA to investigate the direct effects of $\mathrm{CO}_{2}$ and climate change on 3 different forested sites in eastern North America. They concluded that increases in WUE would probably not mitigate the effects of increasing drought stress at these forested sites. In contrast, the results of Post et al. (1992) suggest that forest biomass increases when the direct effects of $\mathrm{CO}_{2}$ are factored into the gap model simulations. At the continental scale, the MAPSS model of Neilson et al. (in press) has been used to investigate an increase in WUE induced by reducing stomatal conductance by $35 \%$. In these simulations, forest loss was reduced from the levels simulated for climate change alone. For the GISS climate change scenario, a forest reduction of $46 \%$ changed to a net increase in forest area of $9 \%$. For the GFDL scenario, an increase in WUE reduced the forest area loss from $92 \%$ to $70 \%$ (Figs. 4 \& 5, Table 1; Neilson et al. in press). Much work remains to be done to incorporate the direct effects of $\mathrm{CO}_{2}$ in a physiologically meaningful manner in vegetation models.

In summary, a doubling of $\mathrm{CO}_{2}$ concentrations over pre-industrial levels (i.e. $280 \mathrm{ppm}$, the approximate atmospheric concentration of $\mathrm{CO}_{2}$ between 1750 and 1800) during the next $100 \mathrm{yr}$ is quite likely, which in turn could cause significant climate change over the same time period. These environmental changes may have large impacts on forest distribution and productivity. Consequently, it is imperative to include environmental change (both climate and $\mathrm{CO}_{2}$ ) in the analysis of forest management options to slow the increase in atmospheric concentrations of $\mathrm{CO}_{2}$.

\section{TOOLS FOR EVALUATING ENVIRONMENTAL CHANGE IMPACTS ON FORESTS}

Incorporating environmental change in forest mitigation planning efforts requires projections of the rate and magnitude of climate change and how these climate changes will affect current and future forest distribution, productivity and biomass. The climate and ecological models that can be used to make these projections are discussed next, together with their strengths and limitations.

\section{Climate models}

A number of different approaches have been suggested for generating scenarios of future climate change caused by increases in greenhouse gas concentrations in the atmosphere (Robinson \& Finkelstein 1989). Arbitrary scenarios (e.g. +2 and $+4^{\circ} \mathrm{C}$, and $\pm 10 \%$ precipitation) have been suggested as a first step in determining the sensitivity of an ecological system to climate perturbations. The limitations of this approach are that the scenarios are, in fact, arbitrary and are not tied to increases in radiative forcing in any physically detailed manner. Also, it is difficult to generate physically consistent arbitrary scenarios without using sophisticated meteorological models if climate variables other than temperature and precipitation are needed to run the desired ecological models (e.g. vapor pressure or wind speed).

Historic analogs have also been used to establish the sensitivity of ecosystems to climate change (e.g. Smith \& Tirpak 1989, Rosenberg \& Crosson 1991). Often the 1930 s drought in the United States is used as an analog. The limitation of using an analog period is that future change is likely to be faster and greater than any change that has occurred over an extended period of time (more than a few months) in the instrumental record. Also, the forcing of earlier (Holocene) climate fluctuations is different from the greenhouse-gas-induced forcing that will drive future climate change. For instance, the increased seasonality of climate (warmer summers and cooler winters) in the northern hemisphere 9000 yr ago was in large part likely caused by 
an increase in summer solar insolation of $8 \%$ and a corresponding decrease in winter insolation (Kutzbach 1987). Greenhouse-gas-induced warming will likely result in warming in both summer and winter (Houghton et al. 1990, 1992).

The remaining approach to generating estimates of future climate is to use physically based climate models. The most sophisticated models available are general circulation models. These models simulate the circulation and physical properties of the atmosphere, including surface meteorological variables. GCMs are based on the fundamental laws of physics, although many of the smaller-scale processes are represented by simplified terms and equations (Houghton et al. 1990, 1992). The advantages of using GCMs center on the fact that they mechanistically simulate the climate effects of increases in greenhouse gases over a 3dimensional spatial grid representing the earth-climate system. They also simulate a wide range of atmospheric variables in a physically consistent manner for the entire globe.

GCMs do a reasonable job at simulating mean global climate conditions, but currently have significant limitations in projecting regional climate patterns (e.g. Bachelet et al. 1992, Houghton et al. 1992). The most significant limitations include: (1) poor spatial resolution; (2) inadequate coupling of atmospheric and oceanic processes; and (3) poor simulation of cloud processes (Gates 1985, Schlesinger \& Mitchell 1985. Dickinson 1986). The coarse spatial resolution (the typical grid cell size in GCMs is $4^{\circ} \times 5^{\circ}$ ) is particularly problematic in regional studies in topographically heterogeneous terrain where climate change is unlikely to be the same across one GCM grid cell (e.g. Dolph et al. 1992). GCMs are improving, especially in regards to coupling atmospheric and oceanic processes. Also the treatment of clouds is improving (Houghton et al. 1992)

Using GCM output to generate climate scenarios is not straightforward because of the biases present in their simulation of current climate. That is, the difference between the simulated value for a climate variable for a grid cell can substantially differ from the observed value in that grid cell (Grotch 1988). Consequently, differences or ratios between the doubled- $\mathrm{CO}_{2}$ and current $\mathrm{CO}_{2}$ model simulations are often used to modify actual historical climate means to produce a doubled $-\mathrm{CO}_{2} \mathrm{cli}$ mate scenario (e.g. Parry et al. 1988, Smith \& Tirpak 1989, Dolph et al. 1992, Smith et al. 1992a, b). More sophisticated approaches for developing climate change scenarios have also been developed. For instance, J. P. Hughes et al. (in press) used a stochastic model to transfer meteorologic information derived from a GCM simulation of sea-level pressure to site-specific measurements of precipitation and temperature.
One of the difficulties in using GCMs in creating climate scenarios is that there are many different GCMs being used to simulate climate change, and several different runs are now available from several modeling groups as they revise their GCMs. Furthermore, GCMs vary in their sensitivity to increases in $\mathrm{CO}_{2}$ concentrations. For instance, the GFDL (Manabe \& Wetherald 1987) and GISS (Hansen et al. 1988) models simulate greater warming under doubled- $\mathrm{CO}_{2}$ conditions than the OSU model (Schlesinger \& Zhao 1989): 4.0 and $4.2^{\circ} \mathrm{C}$ versus $2.8^{\circ} \mathrm{C}$. Also, different GCMs, although perhaps producing similar global scale results, often produce significantly different regional results (e.g. Houghton et al. 1990, 1992). Thus, most studies of climate change effects use multiple GCMs in their analyses, using models that differ in their sensitivity to increases in $\mathrm{CO}_{2}$ concentrations to bound the range of likely future climate change (e.g. Smith \& Tirpak 1989)

Another limitation of GCMs is that many of the runs are equilibrium rather than transient (timedependent) simulations. The rate of climate change is of critical importance for mitigation planning efforts. Simple transient scenarios have been produced assuming that climate will change at a constant rate until the equilibrium conditions are reached (e.g. King \& Neilson 1992, Post et al. 1992, Smith et al. 1992c). In creating this type of scenario, however, one still has to estimate when equilibrium conditions are reached. Transient simulations of climate using coupled atmosphere-ocean GCMs are improving, and at least 4 such model runs have now been completed (Manabe et al. 1991, 1992, Houghton et al. 1992). These model simulations suggest that $60 \%$ of the equilibrium doubled- $\mathrm{CO}_{2}$ warming would have occurred by the time $\mathrm{CO}_{2}$ concentrations doubled (60 to $100 \mathrm{yr}$ in the future depending on the model run; Houghton et al. 1992). The lag in warming is due in part to the thermal inertia of the oceans which is included in the transient simulations. Transient climate scenarios can be generated in the same manner as equilibrium scenarios.

In summary, many quantitative simulations of the equilibrium and transient response of the climate system to increases in greenhouse gas concentrations have been completed. However, these simulations of future climate cannot be viewed as accurate predictions of regional climate change at this time because GCMs still have significant problems in simulating current climate (Houghton et al. 1992). GCMs can be best used to suggest the likely direction and rate of change. As model resolution and parameterization improve, and as different models produce similar future simulations, model output can be increasingly used in a predictive mode. 


\section{Ecological models}

In planning forest management options for sequestering carbon, information is needed as to how climate change will likely impact the future distribution, productivity, and biomass of forests. Several different modeling approaches have been developed for simulating vegetation processes and properties over a variety of spatial and temporal scales. These models will be briefly reviewed here and their relative advantages and disadvantages for simulating climate change impacts summarized. The discussion is organized by the scale of the individual models, and by the ecological properties and processes that they simulate. The specific models discussed in each section are meant to be illustrative rather than a complete listing

The discussion focuses on models that are based more on the fundamental ecophysiological processes that control the distribution and productivity of forested ecosystems than those based on broad empirical relationships between a suite of climate variables and vegetation properties. For example, regression models commonly used to predict forest growth and yield are of limited value in simulating future forest condition under changing climates because the fundamental empirical relationships upon which the models are based may not hold under changing environmental conditions (Prentice et al. 1993a). Changes in carbon dioxide concentrations will render future environmental conditions different from those in which empirical relationships were determined. Consequently, the growth and yield tables that have traditionally been used to predict future yield (e.g. Davis \& Johnson 1987) are inappropriate tools to use in simulating forest growth $50 \mathrm{yr}$ in the future. In that time frame carbon dioxide concentrations will have increased by about $40 \%$ over 1990 levels (Houghton et al. 1992) and climate may have changed. Process-based models (Blake et al. 1990) that incorporate the direct effects of carbon dioxide are likely to be the most accurate tools for simulating forest distribution and growth. The term 'process-based model' is used here to mean a method by which the behavior of an ecosystem or component of an ecosystem is simulated by mathematical representations of the underlying biological processes that control that behavior (Godfrey 1983). Based on our understanding of those biological processes, their mathematical representations can be derived from empirical relationships between the relevant variables if our understanding is limited, or from a cause and effect (mechanistic) understanding of the biological processes (Blake et al. 1990).
Individual tree growth models

Several process-based individual tree growth models have been developed (Bossel \& Schäfer 1989, Dixon et al. 1990). An example of this class of models is TREGRO (Weinstein \& Beloin 1990, Weinstein et al. 1991), which simulates the flux of carbon, water and nutrients through a plant-soil system in response to environmental conditions. Photosynthesis is calculated on a hourly basis as determined by the availability of light, water and nutrients and other ambient environmental conditions. Fixed carbon is allocated to the various compartments within the tree system based on phenological rules and a consideration of the relative requirements of fixed carbon by the individual compartments. The model ultimately simulates tree growth for a period of years.

The advantage of this type of model is that it is physiologically based and the direct effects of $\mathrm{CO}_{2}$ on tree growth can be simulated mechanistically, leading to relatively robust projections of future growth. However, there are several disadvantages in using this type of model for assessing the potential for forest management practices to sequester carbon. Individual tree models must be parameterized using experimental data for the tree species of interest, and experimental data of the detail needed is currently only available for relatively few tree species. Also, most of the experimental data is for seedlings and saplings rather than mature trees. These models commonly do not include ecological processes such as nutrient cycling or disturbance, and only simulate isolated trees. Thus they cannot be directly used to simulate forest stand dynamics. Because of these limitations, one of the best uses of individual tree models is to parameterize growth equations included in ecological models that operate at broader temporal and spatial scales.

\section{Forest gap models}

Forest gap models have undergone rapid development over the past $10 \mathrm{yr}$, with distinct versions available for use in different parts of the world (Shugart et al. 1992). These models are based on the concepts and models developed by Botkin et al. (1972) and Shugart \& West (1977). Gap models simulate forest succession in an opening in a closed forest canopy (typically 0.1 ha) caused by the death of a mature individual. Succession is based on the relative growth rates of competing trees as constrained by a variety of environmental conditions. In the earliest gap models, tree growth was constrained by empirical relationships between tree growth and growing degree days and solar radiation. More recent developments include the addition of soil 
nutrient constraints (e.g. FORTNITE model: Aber \& Melillo 1982; FORTNUT model: Weinstein et al. 1982; LINKAGES model: Pastor \& Post 1985, 1986), soil moisture constraints (FORENA model: Solomon \& Shugart 1984, Solomon 1986), seed dispersal between adjacent plots (ZELIG model: Urban 1990, Urban et al. 1991) and high latitude environmental factors such as permafrost (LOKI model: Bonan 1988, 1989, 1991a, b, c).

The strength of these models is that they do a good job in simulating light competition between individual trees on a forest plot (e.g. Solomon \& West in press). However, many of the environmental relationships that govern growth rates in these models are empirically developed rather than driven mechanistically by ecophysiological processes (e.g. photosynthesis). Thus, simulating the direct effects of $\mathrm{CO}_{2}$ is problematic, as it can only be incorporated by modifying the empirical relationship of tree growth and growing degree days, or tree growth and soil moisture availability (e.g. Post et al. 1992).

Recently, 2 new gap models have been developed that address these limitations. The FORSKA-2 model of Prentice et al. (1993b) includes more physiologically based calculations of net assimilation and sapwood respiration as functions of temperature, growingseason drought, and $\mathrm{CO}_{2}$ fertilization. The growing season drought calculation includes a more detailed calculation of evapotranspiration and overall water balance. The concentration of $\mathrm{CO}_{2}$ affects growth through changes in the annual net assimilation rate and in the half saturation point (defined as the ratio of the light-saturated net assimilation rate to the quantum efficiency of photosynthesis). However, the model does not have any direct effect on soil moisture as of yet.

The HYBRID model of Friend et al. (1993) is derived from 3 models: ZELIG (Urban 1990), a forest gap model; FOREST-BGC (Running \& Coughlan 1988), an ecosystem process model; and PGEN (Friend 1991), a photosynthesis model. The growth equations in ZELIG are replaced with the more mechanistically realistic versions obtained and modified from PGEN and FOREST-BGC. The water balance calculations are made using the approach used in FOREST-BGC. Friend et al. (in press) describe the model as an algorithm for solving for the most advantageous sapwood area in each tree on a site from year to year.

The more advanced forest gap models offer many strengths in the analysis of climate change impacts on forests. They couple ecological processes (disturbance, nutrient cycling, competition) with an increasingly more realistic physiological treatment of tree growth. They can simulate the dynamic response of forests to a changing environment. Furthermore, gap models have been developed for a wide variety of forest types (Shugart et al. 1992). These models are not without their weaknesses, however. They require speciesspecific parameterizations, and the more physiologically detailed they become, the more detailed the parameterizations become (Solomon \& West in press). The models also do not simulate plant migration in response to climate change, and their physiological treatment of the direct effects of $\mathrm{CO}_{2}$ is still being refined. An important aspect of the direct effects of $\mathrm{CO}_{2}$ is its effect on carbon allocation within a tree. The ultimate goal in the revision of gap models is for carbon allocation to be mechanistically treated so that it can change with increasing levels of $\mathrm{CO}_{2}$, if that is indeed what experimental studies suggest (e.g. Norby et al. 1992).

\section{Broad-scale biogeographic models}

Several different types of vegetation models have been developed to simulate continental to global scale changes in potential natural vegetation. The simplest models are based on correlations between plant formations and climate. The Holdridge Life Zone Classification System has been used to simulate the effects of climate change on the global distribution of vegetation (Holdridge 1947, 1967, Emanuel et al. 1985a, b, Prentice 1990, Prentice \& Fung 1990, Smith et al. 1992a, b). Box (1981) developed a second type of broad-scale model based on correlations between the distribution of plant life forms and a suite of climatc variables that describe the seasonality of climate. Bergengren \& Thompson (pers. comm.) have revised the Box model to include competition between life forms in order to predict fractional coverage within each grid cell.

A third class of models is being developed that are more fundamentally based on the physiological mechanisms that control the distribution of plant life forms (BIOME, Prentice et al. 1992; CCVM, Lenihan 1992; MAPSS, Neilson et al. 1992, R. P. Neilson pers. comm.) as proposed by Woodward (1987). One of the most important components of these models is the calculation of site water balance, which controls the distribution and potential maximum biomass of many of the world's forests (Woodward 1987, Neilson et al. 1989, 1992, Stephenson 1990). MAPSS has a sophisticated treatment of water balance in which vegetation cover directly interacts with available soil moisture.

The advantage of this latter class of models is that they are more physiologically based and their simulations of the equilibrium distribution of vegetation under altered climate regimes are likely to be more robust than those based on correlations alone. Also, the mechanistic treatment of water balance allows simple tests of the direct effects of $\mathrm{CO}_{2}$ on plant distribution (Table 1; Neilson et al. in press). Another 
advantage of these models is that they simulate vegetation distribution over broad regions, and thus can be used in country-wide or global assessments of the potential for forest management practices to sequester carbon. The recently developed land-use component (Leemans \& Solomon 1993, this volume, p. 79-96) can be used to suggest where forest mitigation efforts could conflict with other land uses.

The disadvantage of these models as they are currently formulated is that they are equilibrium. approaches and do not simulate the transient course of vegetation response to a changing climate, including plant succession and carbon dynamics. However, they can be used to indicate probable trajectories of vegetation change and the importance of forest dieback in affecting the global carbon cycle (Neilson 1990, Neilson et al. in press). Specifically, they can be used to simulate where forests would be expected to remain unchanged (at the taxonomic resolution of the model). They cannot be used independently to simulate actual global vegetation patterns $100 \mathrm{yr}$ in the future because they do not incorporate migrational or successional processes. Another current limitation of these models is that they do not incorporate biogeochemical processes, especially carbon and nitrogen cycling. The models also do not simulate individual species distributions. Consequently, these models cannot be directly used to simulate carbon storage or to select species for reforestation or afforestation efforts.

\section{Ecosystem process models}

A number of physiologically based ecosystem process models have been developed (e.g. CENTURY, Parton et al. 1988; FOREST-BGC, Running \& Coughlan 1988; GEM, Rastetter et al. 1991). These models simulate canopy photosynthesis, transpiration, litterfall, soil moisture, carbon and nitrogen cycling and net primary productivity at a variety of spatial scales. Agren et al. (1991) review in depth the capabilities of several of these model types and conclude that the models are sufficiently substantiated that their simulations should be viewed as relatively robust. However, Long \& Hutchin (1991) summarize our current uncertainties in scaling up photosynthetic and respiration processes to the ecosystem scale.

The advantage of using these models is that they are physiologically based and some couple productivity with moisture balance and nutrient availability. Some of these models also simulate carbon allocation explicitly and are dynamic, and thus can simulate yearto-year changes in ecosystem processes and carbon storage in response to changing climate (e.g GEM,
Rastetter et al. 1991, 1992). They could be used to simulate the direct effects of enhanced $\mathrm{CO}_{2}$ concentrations on forest productivity. From a forest management perspective, these types of models are limited in their applicability because they generally do not include plant demographic processes such as recruitment, succession, and mortality, and thus cannot simulate changes in carbon storage over time if climate change is large enough to cause a change in forest composition and distribution. However, these models could be used in conjunction with broad-scale biogeographic models to simulate changes in biomass, with the biogeographic models providing the initial constraints on the future distribution of forests at a prescribed time in the future. This would be a useful short-term exercise, but in the longer term carbon and nutrient dynamics will need to be simulated together with plant demographic processes to most accurately model the transient effects of climate change on plant distribution, abundance, and productivity.

\section{Hybrid biogeographic-carbon accounting models}

As described above, no single global or regional scale model currently exists that simulates both the distribution of plant life forms and carbon cycling. Recently, 2 modeling efforts have investigated the potential transient response of global vegetation to climate change and the impact of this response on terrestrial carbon storage (Neilson 1990, King \& Neilson 1992, Smith \& Shugart 1993, Neilson et al. in press). Global vegetation models are used to generate scenarios of future vegetation redistribution. From these vegetation scenarios, different types of forest responses are quantified in order to estimate changes in terrestrial carbon pools. For instance, the total area of forest changing to nonforest is estimated, as is the total area of nonforest changing to forest. These areal estimates are then input into a simple carbon accounting model that keeps track of the amount of carbon lost over time through forest dieback, and the amount of carbon sequestered in areas of regrowth. In the PULSE model (Neilson 1990, King \& Neilson 1992, Neilson et al. in press) carbon loss is simulated to occur through an exponentidl decay process, and carbon accumulation is simulated using a logistic function constrained by a maximum carbon density. Different time lags are assumed in the vegetation response in order to bracket likely rates of change; this was necessary because dynamic global scale vegetation models have not been. developed as of yet. The results from these model analyses suggest that climate-induced vegetation redistribution could make the terrestrial biosphere a transient source of carbon to the atmosphere over the 
next 50 to $100 \mathrm{yr}$. Although this modeling approach would be useful in mitigation planning as described below, the analyses conducted by King \& Neilson (1992) and Smith \& Shugart (1993) did not incorporate current or future land-use. Land-use must be considered in forest management planning in order to accurately estimate the carbon sequestration potential of various management options.

\section{RECOMMENDATIONS FOR INTEGRATING ENVIRONMENTAL CHANGE INTO MITIGATION PLANNING}

Given our current understanding of ecological processes and our predictive tools, how can environmental change be incorporated in the development of mitigation strategies using forest management practices? As reviewed above, we are fairly certain of significant climate change occurring over the next $100 \mathrm{yr}$ and that climate change of this magnitude could have profound effects on the distribution of forests. Whether the direct effects of $\mathrm{CO}_{2}$ on plant physiological processes would substantially reduce the climate change impacts is uncertain. Although our models for simulating regional climate change and for simulating the combined effects of enhanced $\mathrm{CO}_{2}$ concentrations and climate change on vegetation processes need significant improvement to make precise predictions of future forest distribution and productivity, several of the more process-based models can begin to be used in mitigation planning efforts.

To illustrate this, 2 different types of planning issues are considered. One type of planning or assessment activity is estimating the potential for sequestering carbon on a global or regional scale over the next 50 to $100 \mathrm{yr}$ through reforestation, afforestation, or agroforestry efforts (e.g. Winjum et al. 1992). The global scale assessment activities are important for policy makers who must evaluate a range of climate change mitigation efforts including limiting anthropogenic emissions of carbon dioxide. If the sequestration potential of the terrestrial biosphere is high, anthropogenic emissions would not need to be reduced as much to slow the increase in atmospheric carbon dioxide concentrations. The second planning activity to be considered is deciding where forest management activities to increase carbon storage should be targeted first, at both global and regional scales.

\section{Global assessments}

At this time, global assessments incorporating environmental change require the combined use of a number of different models and empirical relationships, because there are no global-scale ecosystem models currently available that simulate both the distribution of plant physiognomic types and carbon dynamics in response to changing environmental conditions. A potential framework for making a global assessment is summarized in Fig. 6. The methodology suggested, although simple, is one that could be implemented over the next 1 or 2 yr. Future model enhancements likely to be completed over the next several years, especially the coupling of carbon and nutrient dynamics with demographic processes in broad-scale models, will enable a more direct and integrated approach for simulating carbon sequestration potential.

Step 1 (Fig. 6) involves generating climate change and atmospheric $\mathrm{CO}_{2}$ scenarios for the time frame of interest, which for forest mitigation planning is often 50 yr (e.g. Winjum et al. 1992). Two approaches can be used. Transient coupled ocean-atmosphere general circulation model simulations (e.g. Manabe et al. 1991, 1992) could be used to generate the climate scenarios. Or, equilibrium GCM scenarios for doubled- $\mathrm{CO}_{2}$ conditions can be used and a linear rate of change assumed to generate the $50 \mathrm{yr}$ climate change scenarios. Multiple climate scenarios (either

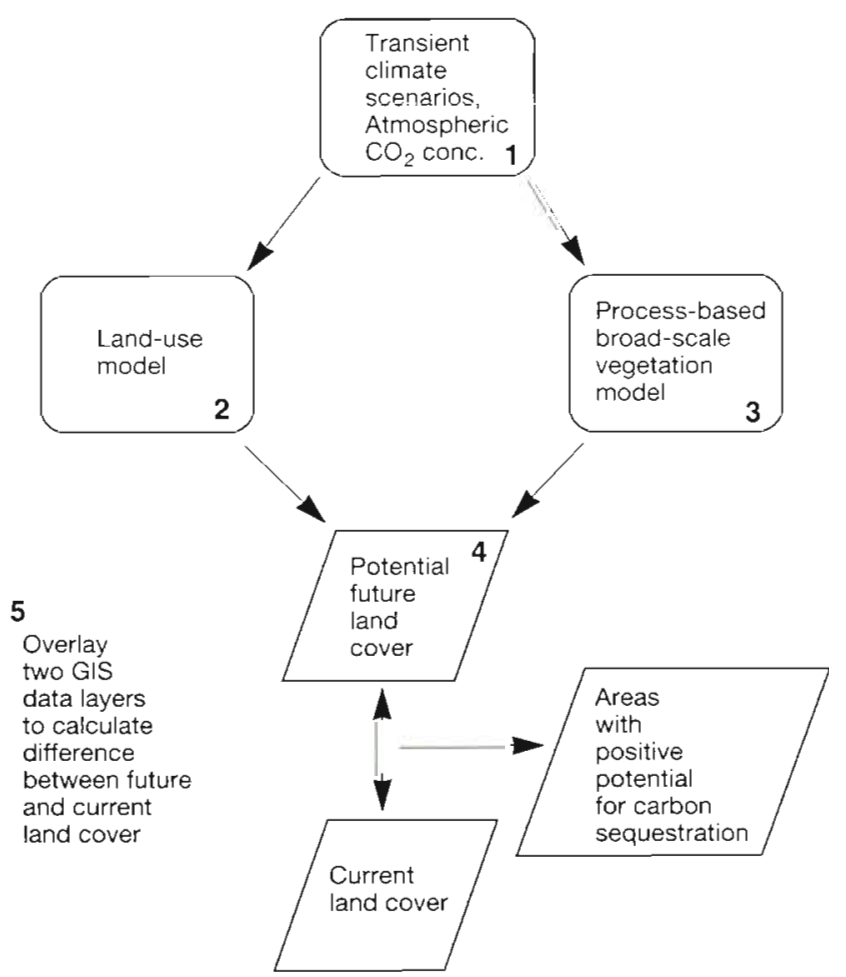

Fig. 6. Schematic of procedure for estimating the potential of forest management options to sequester carbon, taking into account future environmental conditions. See text for additional discussion 
transient or equilibrium) generated from GCMs with different sensitivity to greenhouse-gas forcing should be used to bound the probable range of climate change. Scenarios of changes in atmospheric $\mathrm{CO}_{2}$ concentrations are also needed (e.g. IPCC 1992 scenarios, Houghton et al. 1992), so that the direct effects of $\mathrm{CO}_{2}$ can be incorporated into the assessments.

Steps 2 and 3 involve estimating vegetation redistribution under the altered environmental conditions. The climate change scenarios can be used to drive agricultural land-use models [Cramer \& Solomon 1993 (this volume, p. 97-110), Leemans \& Solomon 1993] and the most process-based broad-scale vegetation models available, currently either the BIOME (Prentice et al. 1992) or CCVM+MAPSS models (Lenihan 1992, Neilson et al. 1992, R. P. Neilson pers. comm.). Multiple models runs should be made for a given climate scenario using different assumptions and model parameterizations of the direct effects of $\mathrm{CO}_{2}$ on vegetation distribution. The multiple runs are needed given the uncertainty in how $\mathrm{CO}_{2}$ could affect vegetation processes. Still, the simulation of vegetation redistribution without incorporating the direct effects of $\mathrm{CO}_{2}$ could give a conservative estimate of carbon sequestration potential. The direct effects of $\mathrm{CO}_{2}$, if manifested at a landscape scale, would mitigate droughtinduced stress and thus increase the area of global forests.

The resulting information on the distribution of potential natural vegetation types and agricultural land use can be combined in a GIS (geographic information system) to produce estimates of future land cover (Step 4). Estimates of future land cover can be overlaid with estimates of current land cover (e.g. Olson et al. 1983, Loveland et al. 1991) to identify areas with the potential to sequester carbon (Step 5). [Current efforts at estimating country-wide carbon budgets (Kurz et al. 1992, D. Turner pers. comm.) will provide useful data on current land cover and biomass of forest types]. A simple rule base (Table 2) can then be used to determine whether a particular grid cell has the potential to sequester carbon. For instance, areas simulated to change to a vegetation cover type with a higher carbon density (e.g. nonforest shifting to forest) satisfy this requirement. Areas where the future potential vegetation land cover is not simulated to change but where the current land use has a lower carbon density than its current potential (e.g. deforested tropical lands) also could be used to sequester carbon. As a first approximation, it could be assumed that current agriculture and urban land use would not change and that simulated new areas of agriculture would take precedence over shifts in natural vegetation. These agricultural and urban areas would not be considered as potential sites for forest management activities.

Quantitative estimates of the sequestration potential in the identified regions/area can be made using several different approaches. First, the current empirical methodology could be applied (e.g. Winjum et al. 1992), in which current data on carbon sequestration rates aggregated by latitudinal band or by region are multiplied by the land available to estimate the carbon sequestration potential. A second approach would be to apply the simple carbon accumulation algorithm in the PULSE model (Neilson et al. in press; or its equivalent in Smith \& Shugart 1993) to the estimates of land available for reforestation. A third and more involved approach would be to adapt an ecosystem process model to estimate changes in forest productivity and biomass. For instance, the biogeographic information could be used to estimate the input parameters (e.g. an estimate of gross primary production) to the GEM model (Rastetter et al. 1991), and that model run to estimate carbon allocation within different forest types. This would be a much more involved and detailed effort than the first two.

An important point about the above analyses is that they will provide an estimate of the maximum amount of carbon that could be sequestered by active reforestation efforts irrespective of cost and logistics. In addition, the actual amount of carbon sequestered by forest management would depend on the effort expended. Furthermore, the carbon sequestration estimates produced by these methods should not be misinterpreted to represent how much total terrestrial

Table 2. Types of land cover change and their potential for increasing carbon storage over current levels

\begin{tabular}{|c|c|c|}
\hline $\begin{array}{l}\text { Potential natural } \\
\text { land cover change }\end{array}$ & $\begin{array}{l}\text { Current } \\
\text { land cover }\end{array}$ & $\begin{array}{l}\text { Sequestration } \\
\text { potential }\end{array}$ \\
\hline Forest to nonforest & Forest or nonforest & $\mathrm{No}^{\mathrm{a}}$ \\
\hline Nonforest to forest & Nonforest & Yes \\
\hline Forest type unchanged & Nonforest & Yes \\
\hline Forest type unchanged & Forest & $\mathrm{N}_{0}{ }^{b}$ \\
\hline $\begin{array}{l}\text { Forest to different } \\
\text { forest type }\end{array}$ & Nonforest & Yes \\
\hline $\begin{array}{l}\text { Forest to different } \\
\text { forest type }\end{array}$ & Forest & $\mathrm{N}_{0}{ }^{c}$ \\
\hline Forest to savanna & Nonforest & Yes \\
\hline Forest to savanna & Forest & $\mathrm{No}^{\mathrm{a}}$ \\
\hline Savanna to forest & Savanna & Yes \\
\hline \multicolumn{3}{|c|}{$\begin{array}{l}\text { a Potential source of carbon to the atmosphere } \\
\text { b Potential carbon sink depending on current carbon density } \\
\text { of forests as opposed to future potential carbon density } \\
\text { 'In the short term, these forest type changes could be a } \\
\text { potential source of carbon to the atmosphere (King \& } \\
\text { Neilson } 1992 \text {, Neilson et al. in press) }\end{array}$} \\
\hline
\end{tabular}


carbon storage could be increased over current levels. It is possible that the overall dynamic response of vegetation to climate change, including the dieback of forests, could temporarily decrease terrestrial carbon storage (King \& Neilson 1992, Smith \& Shugart 1993, Neilson et al. in press) even with a major reforestation effort. If this were the case, the amount of carbon sequestered via forest management would reduce the magnitude of the carbon flux from the biosphere to the atmosphere.

At least one complication to the above conceptual approach is that forested regions that are simulated to change to nonforested regions may still offer some potential for carbon sequestration if they are currently nonforested. The key factors are the rate of change of climate to conditions that would not support forest growth, and the rate of growth of forest tree species that could grow currently under the prevailing climate. In some instances, if the change to nonforested climate conditions occurs relatively late, enough carbon could be sequestered by a fast-growing tree species to warrant a reforestation effort. Analyses using relatively detailed ecological models (e.g. forest gap models) and transient climate scenarios would be needed to determine if forest management efforts in these regions would be feasible.

\section{Regional assessments}

The general methodology for making a regional assessment (with a region being defined to be on the order of several hundred thousand $\mathrm{km}^{2}$, such as the Columbia River Basin in the northwestern United States) is similar to the global scale assessment except that a wider variety of ecological models can be used to simulate future vegetation and carbon density. One way to do the regional assessment is to use the exact same approach and models as for the global assessment, except perhaps with the models run at a finer spatial resolution. Another approach would be to use forest gap models in the analysis if they were available for the types of forested ecosystems that occupy or could occupy a region in the future. Forest gap models would give more detailed vegetation scenarios (i.e. forest composition) than the broad-scale vegetation models and give biomass estimates directly. With this approach, a broad-scale vegetation model is still needed to predict the general character of the regional vegetation under the future climate conditions (e.g. the distribution of grasslands and forests). Then a forest gap model could be used to simulate future species and biomass composition of those areas simulated to remain forested. Individual tree growth models, if available, could also be used to parameterize the forest gap models. The goal again in these analyses is to simulate the potential future vegetation after $50 \mathrm{yr}$, and compare that with current land use and biomass density. Areas for potential carbon sequestration would then be selected following the same general rules outlined in Table 2, but revised to include more specific definitions of forest and vegetation type.

\section{Targeting reforestation/afforestation efforts}

As mentioned earlier, our ability to accurately simulate future environmental change is limited at this time. Regional climate change scenarios generated using several GCMs can differ significantly (e.g. Smith \& Tirpak 1989). Still, decisions may be made by policy makers to pursue reforestation despite the uncertainties in future change, given that forests have other benefits than simply carbon sequestration and that even if reforestation efforts in a region failed after several decades in the future, some carbon would have been sequestered and slowed atmospheric increases in $\mathrm{CO}_{2}$ concentrations. [A related forest management point is, how should forests be managed in the face of changing climate (e.g. Singh \& Wheaton 1991)? What species should be replanted in harvested areas? What areas should be harvested first? The following discussion is relevant to these questions, but these questions will not be addressed specifically as they are beyond the scope of this paper.] Giveñ that decision, how does one target the most suitable areas for beginning reforestation efforts? At a global scale, the goal is to identify regions where it would be least risky to initiate carbon sequestration efforts, and where carbon sequestration rates per unit area would be highest. Here risk is defined to be the probability that climate change will significantly decrease carbon sequestration below current rates, or cause high mortality in the forest plantations.

One straightforward approach is to take the vegetation scenario data created for the global assessment (i.e. follow steps 1 to 4 in Fig. 6) and identify those regions which are forested and simulated to remain forested under future conditions. Any areas within these regions that are currently unforested would be prime targets for reforestation efforts, depending upon other land-use constraints. One complication is that GCMs differ in their simulation of regional climate sensitivity to a doubling of $\mathrm{CO}_{2}$ concentrations. To make the most conservative estimates of the location of potential carbon sequestration sites, several GCM and vegetation change scenarios could be used. Expert judgment could also be used to generate the most reliable climate change scenarios based on outputs from the GCM simulations made to date, as was done in the 1990 IPCC assessment (Houghton et al, 1990). 
The approach outlined above is complicated by the fact that some forested areas that are simulated by a broad-scale biogeographic model to remain in the same broadly defined forest type may in fact undergo large changes in forest species composition. The problem from a sequestration point of view is, what species should be planted in these areas? Since planting decisions are by definition local considerations, more taxonomically precise models (e.g. forest gap models) can be used to make those species selections after the targeted regions have been selected.

Some general conclusions can be made at this time about where or where not to target reforestation efforts given our current understanding of the likely direction of regional climate change based on a qualitative synthesis of climate change simulations (Houghton et al. 1990, 1992). Arctic and northern boreal forest environments are expected to warm significantly more than lower latitudes (Houghton et al. 1992) and many areas now occupied by tundra could become climatically suitable for forest growth. The speed of forest expansion would be determined by the rate of climate warming, availability of propagules, and soil development. Forest management could enhance the speed of forest expansion by the active planting of trees, but only after sufficient warming had taken place. Consequently, these efforts could not be started until some time in the future, and forest management efforts in the near term would be more wisely spent at lower latitudes within currently forested regions. Solomon \& West (in. press) discuss the best models for predicting the success of afforestation efforts in high latitude regions The same types of arguments can be made for an elevational gradient in mountainous regions (recognizing that dispersal of propagules is much less of a problem since the horizontal and vertical distances of movement of forest zones would be much smaller in a mountainous region). Initially, efforts would be best spent at reforesting areas in the current forest zones rather than in alpine areas.

The ecotones of boreal and temperate forests with nonforest vegetation should be carefully evaluated before forest management efforts are initiated there Nonforested land in more arid forest regions may have less water available to buffer increases in drought stress, and thus be more susceptible to dieback than moister regions. In fact, mid-latitude regions may have little potential for carbon sequestration if the more severe vegetation change scenarios are realized (Table 1). An interesting scientific and policy issue is whether biomass on potential forest dieback areas should be reduced by harvesting to reduce water demand and thus prevent dieback of entire forest stands. This would reduce a positive feedback to climate change, but would not necessarily be considered an increase in carbon sequestration following the traditional definitions used in the mitigation literature.

Climate change impacts on tropical forests are uncertain because the development of mechanistic ecological models for these forests has lagged behind the development of temperate forest models. However, since potential carbon storage on wet tropical lands is high, and since deforested lands or thinned forests have a large water surplus, these represent prime targets for reforestation efforts [see Iverson et al. 1993 (this volume, p. 28-38) for a discussion of the potential for sequestering additional carbon in the continental part of tropical Asia].

\section{CONCLUSIONS}

Environmental change over the next hundred years will be at a rate and magnitude unprecedented in the last $10000 \mathrm{yr}$. Over the past decade several studies have suggested how management of forest systems could increase carbon storage in the terrestrial biosphere and thus slow climate change. The results of these studies indicate that reforestation, afforestation, and agroforestry efforts could sequester 1 to $2 \mathrm{Gt}$ of carbon per year for 50 yr (Winjum et al. 1992), a significant fraction of the current yearly increase of $6 \mathrm{Gt}$ of carbon in the atmosphere. However, many of these studies have not factored future environmental change into their estimates, something that needs to be done in order to make the estimates more accurate and policy relevant.

Models that could be used to evaluate the effects of climate change on forests are imperfect but rapidly improving. Within $5 \mathrm{yr}$, ecological models will have greatly improved, but improved climate simulation models may take longer to develop. In the meantime, environmental change can begin to be incorporated into mitigation planning using a variety of processbased models depending on the geographic scale of the planning exercise. The key criteria are to use the most process-based models available at the scale of interest, incorporate $\mathrm{CO}_{2}$ eftects into the model simulations, and simulate a range of climate change and $\mathrm{CO}_{2}$ scenarios to at least bound our uncertainty over future climate change and how forests will respond to enhanced $\mathrm{CO}_{2}$ concentrations. The simple conceptual approaches described here are a first step in an overall effort to incorporate climate change into mitigation planning. They should provide valuable insights into how environmental change could complicate reforestation and afforestation efforts, and what additional 
research and model development is needed to improve our confidence in the simulation of future forest conditions.

Acknowledgements. I thank Dave Peterson, David Tingey, Jack Winjum, and 2 anonymous reviewers for valuable comments on early versions of this manuscript, Jesse Chaney for producing Fig. 1, and Ron Neilson for providing the maps used in Figs. 4 \& 5. The research described in this article was funded by the U.S. Environmental Protection Agency. This document was prepared at the EPA Environmental Research Laboratory in Corvallis, Oregon, through Contract No. 68-C80006 to ManTech Environmental Technology, Inc. It has been subjected to the Agency's peer and administrative review and approved for publication. Mention of trade names or commercial products does not constitute endorsement or recommendation for use

\section{LITERATURE CITED}

Aber, J. D., Melillo, J. M. (1982). FORTNITE: a computer model of organic matter and nitrogen dynamics in forest ecosystems. Research Bulletin R3130. University of Wisconsin, Madison

Ågren, G. I., McMurtrie, R. E., Parton, W. J., Pastor, J., Shugart, H. H. (1991). State-of-the-art of models of production-decomposition linkages in conifer and grassland ecosystems. Ecol. Appl. 1: 118-138

Amthor, J. S., Koch, G. W., Bloom, A. J. (1992). $\mathrm{CO}_{2}$ inhibits respiration in leaves of Rumex crispus L. Plant Physiol. 98: $757-760$

Bachelet, D., Brown, D., Böhm, M., Russell, P. (1992). Climate change in Thailand and its potential impact on rice yield. Clim. Change 21: 347-366

Birdsey, R. A. (1992). Changes in forest carbon storage from increasing forest area and timber growth. In: Sampson, R. N., Hair, D. (eds.) Forests and global change: I. Opportunities for increasing forest cover. American Forests, Washington, DC, p. 23-40

Blake, J. I., Somers, G. L., Ruark, G. A. (1990). Perspectives on process modeling of forest growth responses to environmental stress. ln: Dixon, R. K., Meldahl, R. S., Ruark, G. A., Warren, W. G. (eds.) Process modeling of forest growth responses to environmental stress. Timber Press, Portland, OR. p. $9-17$

Bonan, G. B. (1988). Environmental processes and vegetation patterns in boreal forests. Ph.D. dissertation. University of Virginia, Charlottesville

Bonan, G. B. (1989). A computer model of the solar radiation, soil moisture, and soil thermal regimes in boreal forests. Ecol. Model. 45: 275-306

Bonan, G. B. (1991a). A biophysical surface energy budget analysis of soil temperature in the boreal forests of interior Alaska. Wat. Resour. Res. 27: 767-781

Bonan, G. B. (1991b). Atmosphere-biosphere exchange of carbon dioxide in boreal forests. J. geophys. Res. 96: $7032-7312$

Bonan, G. B. (1991c). Seasonal and annual carbon fluxes in a boreal forest landscape. J. geophys. Res. 96: 17329-17338

Bossel, H., Schäfer, H. (1989). Generic simulation model of forest growth, carbon and nitrogen dynamics. Ecol. Model. 48: 221-265

Botkin, D. B., Janak, J. F., Wallis, J. R. (1972). Some ecological consequences of a computer model of forest growth. J. Ecol. 60: 849-873
Botkin, D. B., Nisbet, R. A., Reynolds, T E. (1989). Effects of climate change on forests of the Great Lakes States. In: Smith, J. B., Tirpak, D. (eds.) Potential effects of global climate change on the United States. EPA-230-05-89-054. U.S. EPA, Washington, DC

Box, E. O. (1981). Macroclimate and plant forms: an introduction to predictive modeling in phytogeography. Dr W. Junk Publishers, The Hague

Bunce, J. A. (1990). Short and long term inhibition of respiratory carbon dioxide efflux by elevated carbon dioxide. Ann. Bot. 65: 637-642

Cramer, W. P., Solomon, A. M. (1993). Climatic classification and future global redistribution of agricultural Iand. Clim. Res. 3: 97-110

Davis, L. S., Johnson, K. N. (1987). Forest management, 3rd edn. McGraw-Hill Book Company, New York

Davis, M. B., Zabinski, C. (1992). Changes in geographical range resulting from greenhouse warming: effects on biodiversity in forests. In: Peters, R. L., Lovejoy, T, E. (eds.) Global warming and biological diversity. Yale University Press, New Haven, CT, p. 297-308

Dickinson, R. E. (1986). How will climate change: the climate system and modelling of future climate. In: Bolin, B. R., Doos, J., Jager, J., Warrick, R. A. (eds.) Scope 29: The greenhouse effect, climatic change and ecosystems. John Wiley, New York, p. 221-231

Dixon, R. K., Meldahl, R. S., Ruark, G. A., Warren, W. G. (eds.) (1990). Process modeling of forest growth responses to environmental stress. Timber Press, Portland, OR

Dixon, R. K., Schroeder, P. E., Winjum, J. K. (eds.) (1991). Assessment of promising forest management practices and technologies for enhancing the conservation and sequestration of atmospheric carbon and their costs at the site level. EPA/600/3-91/067, US Environmental Protection Agency, Corvallis, OR

Dolph, J., Marks, D., King, G. A. (1992). Sensitivity of the regional water balance in the Columbia River Basin to climate variability: application of a spatially distributed water balance model. In: Naiman, R. J. (ed.) Watershed management: balancing sustainability and environmental change. Springer-Verlag, New York, p. 233-265

Drake, B. G. (1992). The impact of rising $\mathrm{CO}_{2}$ on ecosystem production. In: Wisniewski, J., Lugo, A. E. (eds.) Natural sinks of $\mathrm{CO}_{2}$. Kluwer Academic Publishers, Dordrecht, p. 25-34

Eamus, D., Jarvis, P. G. (1989). The direct effects of increase in the global atmospheric $\mathrm{CO}_{2}$ concentration on natural and commercial temperate trees and forests. Adv. ecol. Res. 19: 1-55

Emanuel, W. R., Shugart, H. H., Stevenson, M. P. (1985a). Climatic change and the broad-scale distribution of terrestrial ecosystem complexes. Clim. Change 7: 29-43

Emanuel, W. R., Shugart, H. H., Stevenson, M. P. (1985b). Response to comment: climatic change and the broadscale distribution of terrestrial ecosystem complexes. Clim. Change 7: $457-460$

Friend, A. D. (1991). Use of a model of photosynthesis and leaf microenvironment to predict optimal stomatal conductance and leaf nitrogen partitioning. Plant Cell Environ. 14: 895-905

Friend, A. D., Shugart, H. H., Running, S. W. (1993). A physiology-based gap model of forest dynamics. Ecol. Model. 74: $792-797$

Gates, W. L. (1985). Modeling as a means of studying the climate system. In: MacCracken, M. C., Luther, F. M. (eds.) Projecting the climatic effects of increasing carbon dioxide. DOE/ER-0237, U.S. Department of Energy, Washington, DC, p. $57-79$ 
Godfrey, K. (1983). Compartmental models and their application. Academic Press, New York

Grotch, S. L. (1988). Regional Intercomparisons of general circulation model predictions and historical climate data. DOE/NBB-0084, U.S. Department of Energy, Washington, DC

Hansen, J., Fung, I., Lacis, A., Rind, D., Lebedeff, S., Ruedy, R., Russell, G. (1988). Global climate changes as forecast by Goddard Institute for Space Studies three-dimensional model. J. geophys. Res. 93: 9341-9364

Holdridge, L. R. ( 1947). Determination of world formulations from simple climatic data. Science 105: 367-368

Holdridge, L. R. (1967). Life zone ecology. Tropical Science Center, San Jose, Costa Rica

Houghton, J. T., Callander, B. A., Varney, S. K. (eds.) (1992). Climate change 1992. The supplementary report to the IPCC Scientific Assessment. Cambridge University Press, Cambridge

Houghton, J. T., Jenkins, G. J., Ephraums, J. J. (eds. ) (1990). Climate change. The IPCC Scientific Assessment. Cambridge University Press, Cambridge

Hughes, J. P., Lettenmaier, D. P., Guttorp, P. (in press). A stochastic approach for assessing the effect of changes in regional circulation patterns on local precipitation. Wat. Res.

Iverson, L. R., Brown, S., Grainger, A., Prasad, A., Liu, D. (1993). Carbon sequestration in tropical Asia: an assessment of technically suitable forest lands using geographic information systems analysis. Clim. Res. 3: 23-38

King, G. A., Neilson, R. P. (1992). The transient response of vegetation to climate change: a potential source of $\mathrm{CO}_{2}$ to the atmosphere. In: Wisniewski, J., Lugo, A. E. (eds.) Natural sinks of $\mathrm{CO}_{2}$. Kluwer Academic Publishers, Dordrecht, p. 365-384

Kurz, W. A., Apps, M. J., Webb, T. M., McNamee, P. J. (1992). The carbon budget of the Canadian forest sector: Phase 1. Forestry Canada, Northwest Region. Northern Forestry Centre, Information Report NOR-X-326, Edmonton

Kutzbach, J. E. (1987). Model simulations of the climatic patterns during the deglaciation of North America. In: Ruddiman, W. F., Wright, H. E. Jr (eds.) North America and adjacent oceans during the last deglaciation. Geology of North America, Geological Society of America, v. K-3, Boulder, CO

Leemans, R., Solomon, A. M. (1993). Modeling the potential change in yield and distribution of the earth's crops under a warmed climate. Clim. Res. 3: 79-96

Lenihan, J M. (1992). Canadian vegetation response to climate and projected climatic change. Ph.D. thesis. Oregon State University, Corvallis

Long, S. P., Hutchin, P. R. (1991). Primary production in grasslands and coniferous forests with climate change: an overview. Ecol. Appl. 1. 139-156

Loveland, T. R., Merchant, J W., Ohlen, D. O., Brown, J. F. (1991). Development of a land-cover characteristics database for the conterminous U.S. Photogram. Eng. Rem. Sens. 57: 1453-1463

Manabe, S., Spelman, M. J., Stouffer, R. J. (1992). Transient responses of a coupled ocean-atmosphere model to gradual changes of atmospheric $\mathrm{CO}_{2}$. Part II: Seasonal response. J. Clim. 5: 105-126

Manabe, S., Stouffer, R. J., Spelman, M. J., Bryan, K. (1991). Transient responses of a coupled ocean-atmosphere model to gradual changes of atmospheric $\mathrm{CO}_{2}$. Part I: Annual mean response. J. Clim. 4: 785-818

Manabe, S., Wetherald, R. T (1987). Large-scale changes in soil wetness induced by an increase in carbon dioxide. J. Atmos. Sci. 44: 1211-1235
Mooney, H. A., Drake, B. G., Luxmoore, R. J., Oechel, W. C., Pitelka, L. (1991). Predicting ecosystem responses to elevated $\mathrm{CO}_{2}$ concentrations. BioSci. 41: 96-104

Neilson, R. P. (1990). Biosphere feedback during climate change. In: King, G. A., Winjum, J, K., Dixon, R. K., Arnaut, L. Y (eds.) Response and feedbacks of forest systems to global climate change. EPA/600/3-90/080, U.S. Environmental Protection Agency, Corvallis, OR, p. 73-98

Neilson, R. P., King. G. A. (1992). Continental scale biome responses to climatic change. In: McKenzie, D. H., Hyatt, D. E., McDonald, V. J. (eds.) Ecological indicators, Vol. 2. Elsevier Applied Science, New York, p. 1015-1049

Neilson, R. P., King, G. A., DeVelice, R. L., Lenihan, J., Marks, D., Dolph, J., Campbell, B., Glick, G. (1989). Sensitivity of ecological landscapes and regions to global climate change. EPA/600/3-89/073, NTIS-PB90-120-072/AS, U.S. EPA, Washington, DC

Neilson, R. P., King, G. A., Koerper, G. (1992). Toward a rulebased biome model. Landscape Ecol. 7: 27-43

Neilson, R. P., King, G. A., Lenihan, J. (in press). Modeling forest response to climatic change: the potential for large emissions of carbon from dying forests. In: Proceedings of the IPCC Workshop: Carbon Balance of the Worid's Ecosystems. Publications of the Academy of Finland

Norby, R. J., Gunderson, C. A., Wullschleger, S. D., O'Neill, E. G., McCracken, M. K. (1992). Productivity and compensatory responses of yellow-poplar trees in elevated $\mathrm{CO}_{2}$. Nature 357: 322-324

Olson, J. S., Watts, J. A., Allison, L. J. (1983) Cārbon in live vegetation of major world ecosystems. ORNL-5862, Oak Ridge National Laboratory, Oak Ridge

Parry, M. L., Carter, T. R., Konijin, N. T. (eds.) (1988). The impact of climatic variations on agriculture. Kluwer Academic Publishers, Dordrecht

Parton, W. J., Stewart, J. W., Cole, C. V. (1988). Dynamics of C, N, P and S in grassland soils: a model. Biogeochemistry. 5: $109-131$

Pastor, J., Post, W. M. (1985). Development of a linked forest productivity-soil process model. ORNL/TM-9519, Oak Ridge National Laboratory, Oak Ridge

Pastor, J., Post, W. M. (1986). Response of northern forests to $\mathrm{CO}_{2}$-induced climate change. Nature 334: 55-58

Post, W. M., Pastor, J., King, A. W., Emanuel, W. R. (1992). Aspects of the interaction between vegetation and soil under global change. In: Wisniewski, J., Lugo, A. E. (eds.) Natural sinks of $\mathrm{CO}_{2}$. Kluwer Academic Publishers. Dordrecht, p. 345-364

Prentice, I. C., Cramer, W., Harrison, S. P., Leemans, R., Monserud, R. A., Solomon, A. M. (1992). A global biome model based on plant physiology and dominance, soil properties and climate. J. Biogeogr. 19: 117-134

Prentice, I. C., Monserud, R. A., Smith, T M., Emanuel, W. R. (1993a). Modeling large-scale vegetation dynamics. In: Solomon, A. M., Shugart, H. H. (eds.) Vegetation dynamics and global change. Chapman and Hall, New York, p. $235-250$

Prentice, I C., Sykes, M. T., Cramer, W. (1993b). A simulation model for the transient effects of climate change on forest landscapes. Ecol. Model. 65: 51-70

Prentice, K C. (1990). Bioclimatic distribution of vegetation for GCM studies. J. geophys. Res. 95: 811-830

Prentice, K. C., Fung, I. Y (1990). Bioclimatic simulations test the sensitivity of terrestrial $C$ storage to perturbed climates Nature 346: 48-51

Rastetter, E. B., McKane, R. B., Shaver, G. R., Melillo, J. M. (1992). Changes in $C$ storage by terrestrial ecosystems: how $\mathrm{C}-\mathrm{N}$ interactions restrict responses to $\mathrm{CO}_{2}$ and 
temperature. In: Wisniewski, J, Lugo, A. E. (eds.) Natural sinks of $\mathrm{CO}_{2}$. Kluwer Academic Publishers, Dordrecht, p. $327-344$

Rastetter, E. B., Ryan, M. G., Shaver, G. R., Melillo, J. M., Nadelhoffer, K. J., Hobbie, J. E., Aber, J. D. (1991). A general model describing the responses of the $\mathrm{C}$ and $\mathrm{N}$ cycles in terrestrial ecosystems to changes in $\mathrm{CO}_{2}$, climate and $N$ deposition. Tree Physiol 9: 101-126

Robinson, P. J., Finkelstein, A. E. (1989). Strategies for the development of climate scenarios. AREAL (Atmospheric Research and Exposure Assessment Laboratory), U.S Environmental Protection Agency, Research Triangle Park, NC

Rosenberg, N. J., Crosson, P. R. (1991). The MINK project: a new methodology for identifying regional influences of, and responses to, increasing atmospheric $\mathrm{CO}_{2}$ and climate change. Environ. Conserv. 18: 313-322

Running, S. W., Coughlan, J. C. (1988). A general model of forest ecosystem processes for regional applications. I. Hydrologic balance, canopy gas exchange and primary production processes. Ecol. Model. 42: 125-154

Sampson, R. N. (1992). Forestry opportunities in the United States to mitigate the effects of global warming. In: Wisniewski, J., Lugo, A. E. (eds.) Natural sinks of $\mathrm{CO}_{2}$. Kluwer Academic Publishers, Dordrecht, p. 157-180

Sampson, R. N., Hair, D. (1992). Forests and global change. I: opportunities for increasing forest cover. American Forests, Washington, D.C.

Schlesinger, M. E., Mitchell, J. F. B. (1985). Model projections of the equilibrium climatic response to increased carbon dioxide. In: MacCracken, M. D., Luther, F. M. (eds.) Projecting the climatic effects of increasing carbon dioxide. DOE/ER-0237, U.S. Department of Energy, Washington, DC

Schlesinger, M. E., Zhao, Z. C. (1989). Seasonal climatic change introduced by doubled $\mathrm{CO}_{2}$ as simulated by the OSU atmospheric GCM/mixed-layer ocean model. J. Clim. 2: $429-495$

Schroeder, P. S., Ladd, L. B. (1991). Slowing the increase of atmospheric carbon dioxide: a biological approach. Clim. Change 19: 283-290

Shugart, H. H., Smith. T. M., Post, W. M. (1992). The potential for application of individual-based simulation models for assessing the effects of global change. A. Rev. Ecol. Syst. 23: $15-38$

Shugart, H. H., West, D. C. (1977). Development of an Appalachian deciduous forest succession model and its application to assessment of the impact of the chestnut blight. J. environ. Mgmt. 5: 161-170

Singh, T., Wheaton, E. E. (1991). Boreal forest sensitivity to global warming: implications for forest management in western interior Canada. For. Chron. 67: 342-348

Smith, J. B., Tirpak, D. (eds.) (1989). The potential effects of global climate change on the United States. Report to Congress. EPA-230-05-89-050, U.S. Environmental Protection Agency, Washington, DC

Smith, T. M., Leemans, R., Shugart, H. H. (1992a). Sensitivity of terrestrial carbon storage to $\mathrm{CO}_{2}$-induced climate change: comparison of four scenarios based on general circulation models. Clim. Change 21: 367-384

Smith, T. M., Shugart, H. H. (1993). The transient response of terrestrial carbon storage to a perturbed climate. Nature 361: $523-526$

Smith, T. M., Shugart, H. H., Bonan, G. B., Smith, J. B (1992b). Modeling the potential response of vegetation to global climate change. Adv, ecol. Res. 22: 93-116

Smith, T. M., Weishampel, J. F., Shugart, H. H., Bonan, G. B (1992c). The response of terrestrial $\mathrm{C}$ storage to climate change: modeling $\mathrm{C}$ dynamics at varying temporal and spatial scales. In: Wisniewski, J., Lugo, A. E. (eds.) Natural sinks of $\mathrm{CO}_{2}$. Kluwer Academic Publishers, Dordrecht, p. $307-326$

Solomon, A. M. (1986). Transient response of forests to $\mathrm{CO}_{2-}$ unduced climate change: simulation modeling experiments in eastern North America. Oecologia 68: 567-579

Solomon, A. M., Bartlein, P. J. (1992). Past and future climate change: response by mixed deciduous-coniferous forest ecosystems in northern Michigan. Can. J. For. Res. 22: $1727-1738$

Solomon, A. M., Shugart, H. H. (1984). Integrating forest stand simulations with paleoecological records to examine longterm forest dynamics. In: Ågren, G. 1. (ed.) State and change of forest ecosystems. Swedish University of Agricultural Science, Uppsala, p. 333-356

Solomon, A. M., West, D. C. (1986). Atmospheric carbon dioxide change: Agent of future forest growth or decline? In: Titus, J. G. (ed.) Effects of changes in stratospheric ozone and global climate, Vol. 3, Climate change. U.S Environmental Protection Agency and United Nations Environment Programme, Washington, DC, p. 23-38

Solomon, A. M., West, D. C. (in press.) Predicting afforestation success during climatic warming at the northern limit of forests. In: Alden, J. N., Odum, S., Mastrantonio, J. L (eds.) Proceedings of forest development in cold climates, Laugarvatn, Iceland, June, 1991. Plenum Press, NY

Stephenson, N. L. (1990). Climatic control of vegetation distribution: the role of the water balance. Am. Nat. 135: $649-670$

Tolley, L. C., Strain, B. R. (1985). Effects of $\mathrm{CO}_{2}$ enrichment and water stress on gas exchange of Liquidamber styraciflua and Pinus taeda seedlings grown under different irradiance levels. Oecologia 65: 166-172

Trexler, M. C., Loewen, L. A., Haugen, C. A. (1992). Global warming mitigation through forestry options in the tropics. In: Sampson, R. N., Hair, D. (eds.) Forests and global change. I: Opportunities for increasing forest cover. American Forests, Washington, DC, p. 73-96

Urban, D. L. (1990). A versatile model to simulate forest pattern: a user's guide to ZELIG Version 1.0. Environmental Sciences, University of Virginia, Charlottesville

Urban, D. L., Bonan, G. B., Smith, T. M., Shugart, H. H. (1991) Spatial applications of gap models. For. Ecol. Manage. 42 : 95-110

Urban, D. L., Shugart, H. H. (1989). Forest response to climatic change: a simulation study for southeastern forests. In: Smith, J. B., Tirpak, D. (eds.) The potential effects of global climate change on the United States. EPA-230-05-89-050, U.S. Environmental Protection A.gency, Washington, DC

Webb, T. III (1989). The spectrum of temporal climatic variability: current estimates and the need for global and regional time series. In: Bradley, R. S. (ed.) Global changes of the past, University Corporation for Atmospheric Research, Oxford Institute for Energy Studies, Boulder, CO, p. 61-81

Weinstein, D. A., Beloin, R. (1990). Evaluating effects of pollutants on integrated tree processes: a model of carbon water and nutrient balances. In: Dixon, R. K., Meldahl, R. S., Ruark, G. A., Warren, W. G. (eds.) Process modeling of forest growth responses to environmental stress. Timber Press, Portland, OR, p. 313-323

Weinstein, D. A., Beloin, R. M., Yani, R. D. (1991). Modeling changes in red spruce carbon balance and allocation in response to interacting ozone and nutrient stress. Tree Physiol. 9: 127-146 
Weinstein, D. A., Shugart, H. H., West, D. C. (1982). The longterm nutrient retention properties of forest ecosystems: a simulation investigation. Report ORNL/TM-8472, Oak Ridge National Laboratory, Oak Ridge

Wigley, T M. L., Raper, S. C. B. (1992). Implications for climate and sea level of revised IPCC emissions scenarios. Nature 357: 293-300
Winjum, J. K., Dixon, R. K., Schroeder, P. E. (1992). Estimating the global potential of forest and agroforest management practices to sequester carbon. In: Wisniewski, J., Lugo, A. E. (eds.) Natural sinks of $\mathrm{CO}_{2}$. Kluwer Academic Publishers, Dordrecht, p. 213-228

Woodward, F. I. (1987). Climate and plant distribution. Cambridge University Press, London 